\title{
Aesthetic assessment of a facial profile according to mandibular position
}

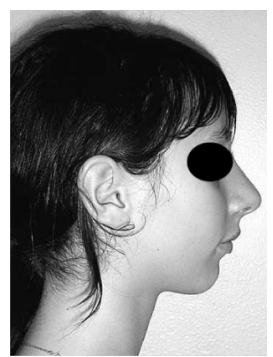

\author{
Jessy LHOTELLIER, Cécile LEBRAZIDEC, \\ Olivier SOREL
}

\begin{abstract}
The relevance of this paper consists in comparing the practitioner's view to general public opinion. Orthodontists learned to evaluate facial profiles in a critical way, with reference to standards. They have developed personal appreciations to gauge a balanced profile. But, because orthodontic treatment implies achieving an aesthetic effect, the practitioner must know what is the optimal objective according to the public opinion. Our study deals with the aesthetic assessment of teenagers' profiles in Class II (Corner and Ballard) by professional examiners and lay people. These profiles have been modified by simulating mandibular protrusion.
\end{abstract}

\section{KEYWORDS}

Facial aesthetic

Balanced profile

Mandibular projection. 


\section{1 - INTRODUCTION}

The rationalisation of orthodontic treatments leads to evaluate aesthetic modifications, which is one of the main patient's objective Aesthetic assessment in orthodontics is different from the public opinion's evaluation. Recent studies were made thanks to a methodology of evaluation: the definition of beauty perception by a social group (called the jury) in a selected population.

According to Faure ${ }^{6}$, "aesthetic judgement is, by definition, a strictly

\section{2 - MATERIAL AND METHOD}

\section{2 - 1 - Study purpose}

The practitioner's hard and soft tissue evaluation is based on cephalomtric as well as aesthetic norms. But he must also take patients' desires into account.

The purpose of this paper is to evaluate aesthetic preferences in a selected population and see whether these preferences suit contemporary orthodontic norms $1,2,4,5,8,9$.

\section{2 - 2 - Definition of the analysed sample and construction of the different profiles}

\section{2 - 2 - 1 - The sample}

\section{- Choice of the reference sample}

We have selected six subjects (three males, three females) amongst patients cured at the orthodontic unit of the Rennes hospital. Patients are young teenagers from 11 to 13 for personal matter and therefore purely subjective". But, if we widen his judgement to a defined group of people, we approach beauty in a probabilistic way: so we can define a homogeneous probability law by an aesthetic mark or score. "Social aesthetics "6 integrates the public opinion who may tell us whether the chosen orthodontic treatment brings an aesthetic improvement or not.

whom we did not require any aesthetic criterion.

Other criterions were:

- caucasian typology,

- facial symetry,

- belonging to long, normal, short face typologies, and to both sexes,

- skeletal class II relationship with a retrognathic mandible,

- dental class II, molar and canine,

- absence or moderate dental crowding,

- no history of previous orthodontic or orthopaedic treatment.

For each subject, front view and right profile photographs, orthopantomography and profile teleradiography were systematically performed and studied to affirm selection criteria.

- Construction of the appreciation paper, and presentation to the jury

Genuine coloured profile photographs have been modified with 
the help of Photoshop $^{\circledR}$ software: they were turned into black and white; brightness and contrast were modified so as to reduce aesthetic elements (such as cutaneous texture, colour of skin, colour of hair) which are not taken into account in the study, as the orthodontic treatment has no consequence on them. But, contrary to other studies (Rhodes $^{14}$, Werli ${ }^{18}$ ), we did not systematically disguised the profiles by using standardised hairstyle or composite portraits. Once genuine profiles of each teenager were prepared in black and white, we achieved a progressive animation of the profile by morphing (from Hier, et al. ${ }^{8}$ method). Our study concerns different chin positions with the same profile; the obtained distorsions simulating a mandibular advancement will be submitted to the jury appreciation in a second time.

We managed that simulation thanks to the Morpheus Animation Photo ${ }^{\circledR}$ software. We selected ten cutaneous points for every genuine picture.

- Pronasal and subnasal points maintain the nasal height.

- The cutaneous A point keeps the superior labial convexity.

- The superior labial point controls the projection of the superior lip. When linked with the subnasal point, we are able to modify the naso labial angle.

- The porion maintains a contact between the lips.

- The inferior labial point controls the projection of the inferior lip.

- The cutaneous B point maintains the initial line between the chin and the inferior lip.
- Finally, the cutaneous pogonion point, the chin point and the gnathion point bring the chin $3 \mathrm{~mm}$ forward, by simulating an average orthopaedic action.

The software recorded chin profile distorsion in a fifteen-picture film. We kept the genuine profile, the $7^{\text {th }}$ picture (corresponding to the intermediate mandibular position), and the $15^{\text {th }}$ (corresponding to the maximum mandibular position). To carry out the appreciative paper, we lined up the three profiles for each patient (six lines all in all numbered from 1 to 6 , three girls then three boys) mixing the profiles on three columns to a random event. Mixing this simulation allowed us to avoid any bias in the judgment from the juries (annex).

\section{2 - 3 - Jury selection and questionnaire presentation}

\section{2 - 3 - 1 - Jury chosen}

We shared out the answers amongst three juries (table 1 and 2).

\begin{tabular}{|c|c|}
\hline Type & \\
\hline $\mathrm{Et}$ & 36 \\
\hline $\mathrm{Pr}$ & 31 \\
\hline $\mathrm{Pu}$ & 34 \\
\hline
\end{tabular}

Table I

Distribution of the three juries.

$E t=$ dental students,

$\mathrm{Pr}=$ practitioners,

$P u=$ public or lay people. 
Annex. Profile photographs distribution and construction of the appreciation paper.

A
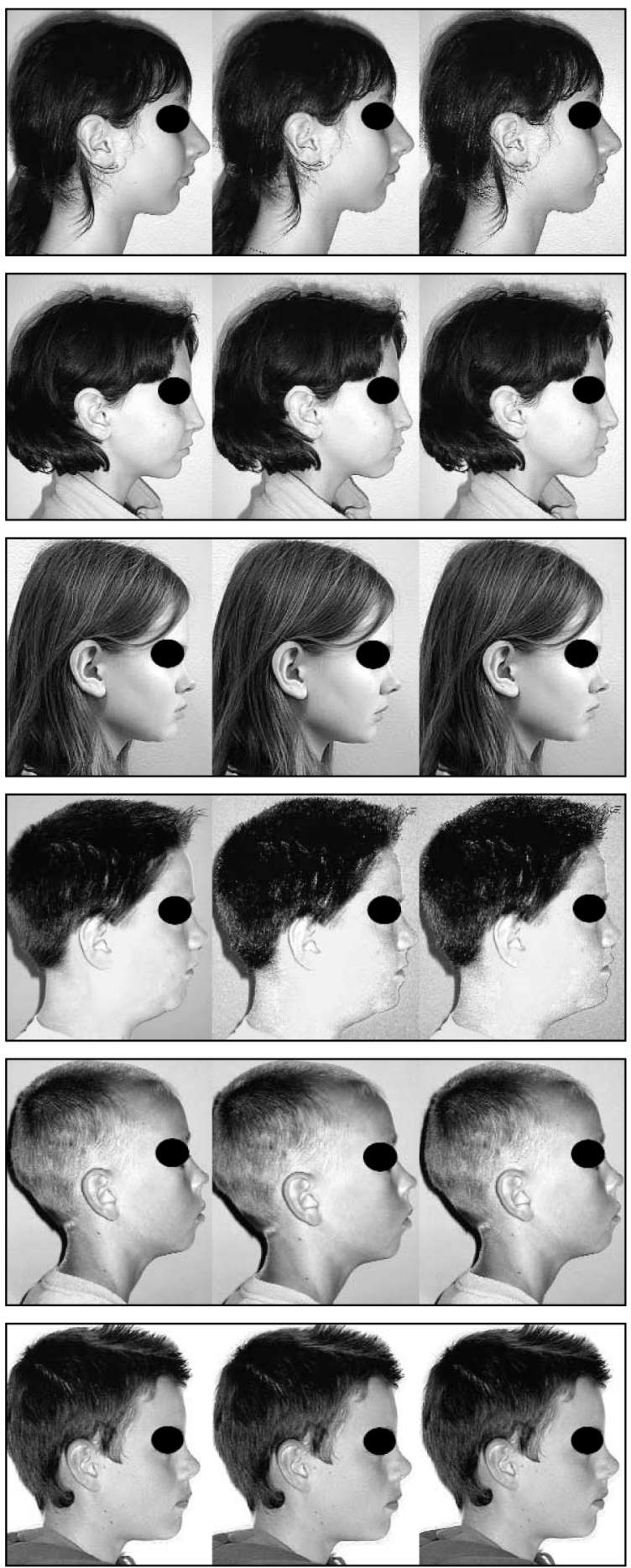

\begin{tabular}{|c|c|c|c|}
\hline & profile $A$ & profile B & profile C \\
\hline $\begin{array}{l}\text { PATIENT } 1 \\
\text { Sexe: female } \\
\text { Type facial: } \\
\text { long face } \\
\text { typology }\end{array}$ & Normal profile & $\begin{array}{l}\text { Intermediate } \\
\text { profile }\end{array}$ & $\begin{array}{l}\text { Most uptight } \\
\text { profile }\end{array}$ \\
\hline $\begin{array}{l}\text { PATIENT } 2 \\
\text { Sexe: female } \\
\text { Type facial: } \\
\text { normal face } \\
\text { typology }\end{array}$ & Normal profile & $\begin{array}{l}\text { Most uptight } \\
\text { profile }\end{array}$ & $\begin{array}{l}\text { Intermediate } \\
\text { profile }\end{array}$ \\
\hline $\begin{array}{l}\text { PATIENT } 3 \\
\text { Sexe: female } \\
\text { Type facial: } \\
\text { short face } \\
\text { typology }\end{array}$ & $\begin{array}{l}\text { Most uptight } \\
\text { profile }\end{array}$ & Normal profile & $\begin{array}{l}\text { Intermediate } \\
\text { profile }\end{array}$ \\
\hline $\begin{array}{l}\text { PATIENT } 4 \\
\text { Sexe: male } \\
\text { Type facial: } \\
\text { long face } \\
\text { typology }\end{array}$ & Normal profile & $\begin{array}{l}\text { Most uptight } \\
\text { profile }\end{array}$ & $\begin{array}{l}\text { Most uptight } \\
\text { profile }\end{array}$ \\
\hline $\begin{array}{l}\text { PATIENT } 5 \\
\text { Sexe: male } \\
\text { Type facial: } \\
\text { normal face } \\
\text { typology }\end{array}$ & $\begin{array}{l}\text { Intermediate } \\
\text { profile }\end{array}$ & Normal profile & $\begin{array}{l}\text { Most uptight } \\
\text { profile }\end{array}$ \\
\hline $\begin{array}{l}\text { PATIENT } 6 \\
\text { Sexe: male } \\
\text { Type facial: } \\
\text { short face } \\
\text { typology }\end{array}$ & $\begin{array}{l}\text { Most uptight } \\
\text { profile }\end{array}$ & $\begin{array}{l}\text { Intermediate } \\
\text { profile }\end{array}$ & Normal profile \\
\hline
\end{tabular}




\begin{tabular}{|c|c|c|c|c|}
\hline \multicolumn{5}{|l|}{ Type Et } \\
\hline & \multicolumn{2}{|c|}{ Type } & \multirow{2}{*}{\multicolumn{2}{|c|}{ Total }} \\
\hline & \multicolumn{2}{|c|}{ Et } & & \\
\hline & Effectif & $\%$ col & Effectif & $\%$ col \\
\hline Subtype & \multirow[b]{2}{*}{78} & \multirow[b]{2}{*}{36.11} & \multirow[b]{2}{*}{78} & \multirow[b]{2}{*}{36.11} \\
\hline D2 & & & & \\
\hline D3 & 72 & 33.33 & 72 & 33.33 \\
\hline T1 & \multicolumn{2}{|r|}{30.56} & 66 & 30.56 \\
\hline \multicolumn{5}{|l|}{ Type Pr } \\
\hline & \multicolumn{2}{|c|}{ Type } & \multirow{2}{*}{\multicolumn{2}{|c|}{ Total }} \\
\hline & \multicolumn{2}{|c|}{$\operatorname{Pr}$} & & \\
\hline & Effectif & $\%$ col & \multicolumn{2}{|c|}{\begin{tabular}{l|l} 
Effectif & $\%$ col
\end{tabular}} \\
\hline \multicolumn{5}{|l|}{ Subtype } \\
\hline Dentists & 102 & 54.84 & 102 & 54.84 \\
\hline Orthodontists & 84 & 45.16 & 84 & 45.16 \\
\hline
\end{tabular}

Table II

Distribution of the subtypes.
- A general public jury, illustrating the patient's request which is to please himself and his family. Since it cannot be possible to differentiate aesthetic judgement indefinitely, we selected an average jury of 34 people from Brittany and from the odontology unit of the Rennes Academic Hospital Complex. They belong to different social backgrounds as varied as possible (medical students, secondary school pupils, dental assistants, secretaries, fine arts students, technicians, retired people).

- A panel of dental students studying in Rennes: 13 are in their $4^{\text {th }}$-year course, 12 in their $5^{\text {th }}, 11$ in their $6^{\text {th }}$. They represent the turning point between the general public and the practitioners.

- A professional jury made with 17 dentists and 14 orthodontists. How- ever, the opinion of a professional jury is relevant only if compared to the one of general public's.

\section{2 - 3 - 2 - Type of question and judgement terms}

We asked the jury to grade by preference the three profiles of each patient so that they could give a more precise answer. They could not be neutral by giving an average mark.

Then, they briefly had to justify their choices by answering to simple questions. The questions were quite easy and directly focused on aesthetic profile. Each member jury was isolated from the others and provided an individual answer. 


\section{2 - 4 - Statistical method}

We sent 200 questionnaires to the different jurys. 166 came back to us and 101 were correctly filled.

We wrote out the answers on an Excel sheet: each piece of a jury were identified by a number. We added the type of jury (and the subtype), their first choice (his preferred profile for each patient), their third choice (the profile he liked worst), and the sex of the patient.

We captured and analysed this information with the SAS software and with the help from the Medical Computing Department of The Rennes Academic Hospital Complex. The main aims of these criteria are to find out a link between two qualitative variables. The data were analysed in 3 different ways: simple numbering (frequency, number of jurys), percentage and then statistics.

The software has crossed data to highlight the decreasing preferences (called choice 1 and choice 2) depending on the type of jury, then the subtype (for every type of jury except the public), patient sex, and finally profile typology (is the personal eva-

\section{3 - RESULTS}

\section{3 - 1 - Most chosen profiles}

\section{3 - 1 - 1 - According to the jury \\ - On general points: share out of the preferences}

Dental surgery students' jury and practitioners (dentists and orthodontists) appreciate an intermediate man- luation different in front of a normo, hypo or hyperdivergent patient?).

For each sheet, we copied out frequency and the percentage of subjects (corresponding to the three profiles: normal, intermediate and maximum), and preference percentages in line and column. Missing frequencies are the incomplete answers in the crossed table.

We statistically analysed the data with the SAS software and with the GENMOD procedure. We used a model based on repeated measures to take the correlation between all answers (every patient leads to 100 answers) into account. The significance level is $5 \%$.

We ran two separate analyses:

- the first one refers to the probability of chosing the most uptight profile compared to the one of prefering the normal one; and this for each factor that may influence the choice: type of jury (public, students, practitioners), sex of the patient and his facial profile;

- the second analysis refers to the probability prefering an intermediate profile to a normal profile, according to those three factors. dibular position (this means a light advancement of both chin and inferior lip in the profile) whereas the public prefered a normal mandibular position. This means an initial skeletal class II profile (table 3 ).

\section{- Preferences in each jury accord- ing the subtype}




\begin{tabular}{|c|c|c|c|c|}
\hline \multicolumn{5}{|c|}{ Table de type par Choix 1} \\
\hline Type & & 10ix 1 & & \multirow[b]{2}{*}{ Total } \\
\hline $\begin{array}{l}\text { Pourcentage } \\
\text { Pct en ligne } \\
\text { Pct en col. }\end{array}$ & $\begin{array}{r}\text { Position } \\
\text { Inter }\end{array}$ & $\begin{array}{r}\text { Position } \\
\text { Max }\end{array}$ & $\begin{array}{c}\text { Position } \\
\text { Normal }\end{array}$ & \\
\hline Et & $\begin{array}{r}99 \\
16.56 \\
\mathbf{4 5 . 8 3} \\
39.44\end{array}$ & $\begin{array}{r}62 \\
10.37 \\
28.70 \\
38.04\end{array}$ & $\begin{array}{r}55 \\
9.20 \\
25.46 \\
29.89\end{array}$ & $\begin{array}{r}216 \\
36.12\end{array}$ \\
\hline $\operatorname{Pr}$ & $\begin{array}{r}80 \\
13.38 \\
\mathbf{4 4 . 4 4} \\
31.87\end{array}$ & $\begin{array}{r}52 \\
8.70 \\
28.89 \\
31.90\end{array}$ & $\begin{array}{r}48 \\
8.03 \\
26.67 \\
26.09\end{array}$ & $\begin{array}{r}180 \\
30.10\end{array}$ \\
\hline $\mathrm{Pu}$ & $\begin{array}{r}72 \\
12.04 \\
35.64 \\
28.69\end{array}$ & $\begin{array}{r}49 \\
8.19 \\
24.26 \\
30.06\end{array}$ & $\begin{array}{r}81 \\
13.55 \\
40.10 \\
44.02\end{array}$ & $\begin{array}{r}202 \\
33.78\end{array}$ \\
\hline Total & $\begin{array}{r}251 \\
41.97\end{array}$ & $\begin{array}{r}163 \\
27.26\end{array}$ & $\begin{array}{r}184 \\
30.77\end{array}$ & $\begin{array}{r}598 \\
100.0\end{array}$ \\
\hline \multicolumn{5}{|c|}{ Fréquence manquante $=8$} \\
\hline
\end{tabular}

Table III

Preferences in each jury according to mandibular position.
Fourth-year-course students tolerate the intermediate profile as well as the maximum profile $137 \%$ and $38.5 \%$ ), whereas older students (fifth and sixth-year-course students) did prefer intermediate profiles (47 and $54.5 \%)$. Dentists show their preference for the intermediate profile $(50.5 \%)$ while orthodontists are divided between intermediate and maximum profiles (37.5 and 36\%) (table 4 and 5).

It is quite interesting to note that students get an opinion closer to the one of orthodontists as they progress in their professional education. Orthodontists are the one who prefer the most protruding chin.

\section{3 - 1 - 2 - According to patient sex}

Juries' preferences are divided between intermediate and normal chin position for girls (39.7 and 34\%) maybe more swanlike, while for boys, they much prefer the intermediate position $(44.5 \%)$.

Students and practitioners opt for an intermediate female profile $(42.5 \%)$ whereas public has a marked preference for the normal profile before treatment $(43 \%)$.

Students and practitioners also tolerate more easily an intermediate male profile (49 and $47 \%$ ), while the public is fairly divided between normal 


\begin{tabular}{|c|c|c|c|c|}
\hline \multicolumn{5}{|c|}{ Table de Sous-type d'étudiants par Choix 1} \\
\hline Type & & Choix 1 & & \\
\hline $\begin{array}{l}\text { FREQUENCE } \\
\text { Pourcentage } \\
\text { Pct en ligne } \\
\text { Pct en col. }\end{array}$ & $\begin{array}{r}\text { Position } \\
\text { Inter }\end{array}$ & $\begin{array}{r}\text { Position } \\
\text { Max }\end{array}$ & $\begin{array}{c}\text { Position } \\
\text { Normal }\end{array}$ & Total \\
\hline D2 & $\begin{array}{r}29 \\
13.43 \\
37.18 \\
29.29\end{array}$ & $\begin{array}{r}30 \\
13.89 \\
\mathbf{3 8 . 4 6} \\
48.39\end{array}$ & $\begin{array}{r}19 \\
8.80 \\
24.36 \\
34.55\end{array}$ & $\begin{array}{r}78 \\
36.11\end{array}$ \\
\hline D3 & $\begin{array}{r}34 \\
15.74 \\
47.22 \\
34.34\end{array}$ & $\begin{array}{r}14 \\
6.48 \\
19.44 \\
22.58\end{array}$ & $\begin{array}{r}24 \\
11.11 \\
33.33 \\
43.64\end{array}$ & $\begin{array}{r}72 \\
33.33\end{array}$ \\
\hline T1 & $\begin{array}{r}36 \\
16.67 \\
\mathbf{5 4 . 5 5} \\
36.36\end{array}$ & $\begin{array}{r}18 \\
8.33 \\
27.27 \\
29.03\end{array}$ & $\begin{array}{r}12 \\
5.56 \\
18.18 \\
21.82\end{array}$ & $\begin{array}{r}66 \\
30.56\end{array}$ \\
\hline Total & $\begin{array}{r}99 \\
45.83\end{array}$ & $\begin{array}{r}62 \\
28.70\end{array}$ & $\begin{array}{r}55 \\
25.46\end{array}$ & $\begin{array}{r}216 \\
100.0\end{array}$ \\
\hline
\end{tabular}

Table IV

Preferences according to the students subtype.

\begin{tabular}{|c|c|c|c|c|}
\hline \multicolumn{5}{|c|}{ Table de sexe par Choix 1} \\
\hline Type & & Choix 1 & & \\
\hline $\begin{array}{l}\text { FREQUENCE } \\
\text { Pourcentage } \\
\text { Pct en ligne } \\
\text { Pct en col. }\end{array}$ & $\begin{array}{r}\text { Position } \\
\text { Inter }\end{array}$ & $\begin{array}{r}\text { Position } \\
\text { Max }\end{array}$ & $\begin{array}{c}\text { Position } \\
\text { Normal }\end{array}$ & Total \\
\hline $\mathbf{F}$ & $\begin{array}{r}119 \\
19.90 \\
39.67 \\
47.41\end{array}$ & $\begin{array}{r}79 \\
13.21 \\
26.33 \\
48.47\end{array}$ & $\begin{array}{r}102 \\
17.06 \\
\mathbf{3 4 . 0 0} \\
55.43\end{array}$ & $\begin{array}{r}300 \\
50.17\end{array}$ \\
\hline M & $\begin{array}{r}132 \\
22.07 \\
44.30 \\
52.59\end{array}$ & $\begin{array}{r}84 \\
14.05 \\
28.19 \\
51.53\end{array}$ & $\begin{array}{r}82 \\
13.71 \\
27.52 \\
44.57\end{array}$ & $\begin{array}{r}298 \\
49.83\end{array}$ \\
\hline Total & $\begin{array}{r}251 \\
41.97\end{array}$ & $\begin{array}{r}163 \\
27.26\end{array}$ & $\begin{array}{r}184 \\
30.77\end{array}$ & $\begin{array}{r}598 \\
100.0\end{array}$ \\
\hline
\end{tabular}

Table IV

Preferences according to patient sex.

\begin{tabular}{|c|c|c|c|c|}
\hline Type & \multicolumn{3}{|c|}{ Choix 1} & \multirow[b]{2}{*}{ Total } \\
\hline $\begin{array}{l}\text { FREQUENCE } \\
\text { Pourcentage } \\
\text { Pct en ligne } \\
\text { Pct en col. }\end{array}$ & $\begin{array}{r}\text { Position } \\
\text { Inter }\end{array}$ & $\begin{array}{r}\text { Position } \\
\text { Max }\end{array}$ & $\begin{array}{c}\text { Position } \\
\text { Normal }\end{array}$ & \\
\hline Dentiste & $\begin{array}{r}49 \\
27.22 \\
\mathbf{5 0 . 5 2} \\
61.25\end{array}$ & $\begin{array}{r}22 \\
12.22 \\
22.68 \\
42.31\end{array}$ & $\begin{array}{r}26 \\
14.44 \\
26.80 \\
54.17\end{array}$ & $\begin{array}{r}97 \\
53.89\end{array}$ \\
\hline ODF & $\begin{array}{r}31 \\
17.22 \\
37.35 \\
38.75\end{array}$ & $\begin{array}{r}30 \\
16.67 \\
\mathbf{3 6 . 1 4} \\
57.69\end{array}$ & $\begin{array}{r}22 \\
12.22 \\
26.51 \\
45.83\end{array}$ & $\begin{array}{r}83 \\
46.11\end{array}$ \\
\hline Total & $\begin{array}{r}80 \\
44.44\end{array}$ & $\begin{array}{r}52 \\
28.89\end{array}$ & $\begin{array}{r}48 \\
26.67\end{array}$ & $\begin{array}{r}180 \\
100.0\end{array}$ \\
\hline \multicolumn{5}{|c|}{ Fréquence manquante $=6$} \\
\hline
\end{tabular}

Table $\mathrm{V}$

Preference according to practitioners (dentists and orthodontists).

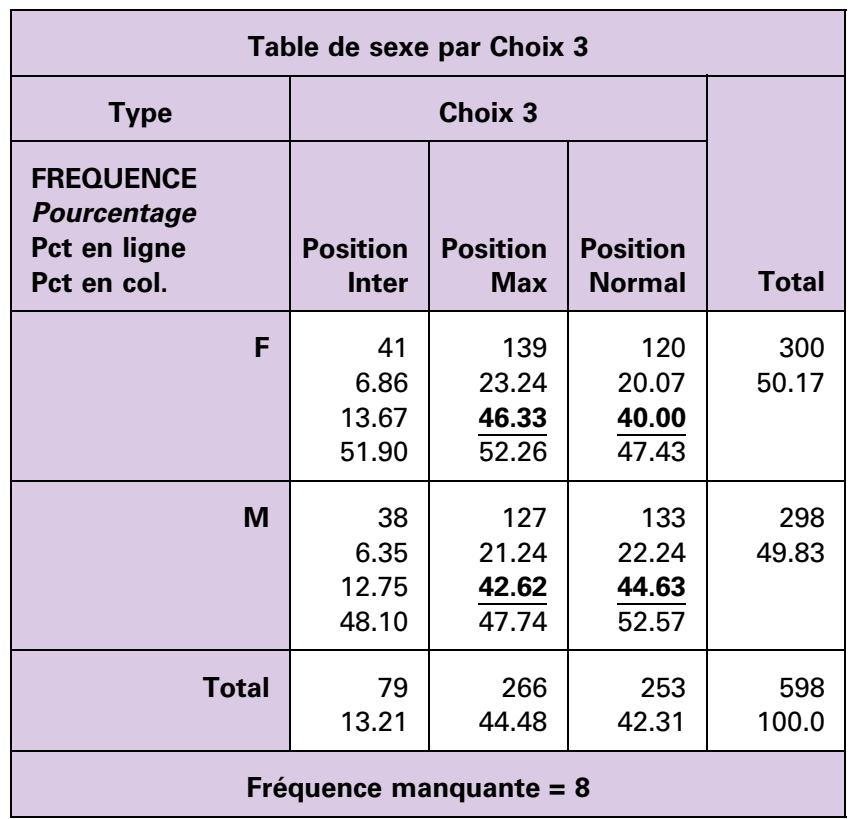

Table VI bis

Distribution of choice 3 in each jury according to patient sex. 


\begin{tabular}{|c|c|c|c|c|}
\hline \multicolumn{5}{|c|}{ Table de type par Choix $1 \mathrm{chez}$ les filles } \\
\hline \multirow{2}{*}{\begin{tabular}{l}
\multicolumn{1}{c}{ Type } \\
FREQUENCE \\
Pourcentage \\
Pct en ligne \\
Pct en col.
\end{tabular}} & \multicolumn{3}{|c|}{ Choix 1} & \multirow[b]{2}{*}{ Total } \\
\hline & $\begin{array}{r}\text { Position } \\
\text { Inter }\end{array}$ & $\begin{array}{r}\text { Position } \\
\text { Max }\end{array}$ & $\begin{array}{l}\text { Position } \\
\text { Normale }\end{array}$ & \\
\hline \multirow[t]{4}{*}{ Et } & 46 & 27 & 35 & 108 \\
\hline & 15.33 & 9.00 & 11.67 & 36.00 \\
\hline & 42.59 & 25.00 & 32.41 & \\
\hline & $\overline{38.66}$ & 34.18 & 34.31 & \\
\hline \multirow[t]{4}{*}{$\operatorname{Pr}$} & 39 & 29 & 24 & \\
\hline & 13.00 & 9.67 & 8.00 & 30.67 \\
\hline & 42.39 & 31.52 & 26.09 & \\
\hline & $\overline{32.77}$ & 36.71 & 23.53 & \\
\hline \multirow[t]{4}{*}{$\mathrm{Pu}$} & 34 & 23 & 43 & 100 \\
\hline & 11.33 & 7.67 & 14.33 & 33.33 \\
\hline & 34.00 & 23.00 & 43.00 & \\
\hline & 28.57 & 29.11 & $\overline{42.16}$ & \\
\hline \multirow[t]{2}{*}{ Total } & 119 & 79 & 102 & 300 \\
\hline & 39.67 & 26.33 & 34.00 & 100.0 \\
\hline \multicolumn{5}{|c|}{ Fréquence manquante $=3$} \\
\hline
\end{tabular}

Table VII

Preference in each jury for female mandibular position.

and intermediate profile $(37.25 \%)$ (table 6, 6bis, 7 and 8).

In other words, the whole jury would not appreciate a too much protruding chin or the contrary, whatever the sex of the patient is. We must take into account the fact that we study teenagers' profiles which did not get sexed characteristics yet.

\section{3 - 1 - 3 - According to facial typology}

For long face patients (male and female), juries prefer an intermediate or a maximum profile (48 and $44 \%$ ) (table 9). The increase of lower facial height tends to make mandibular retrognathia more pronounced. This ex-

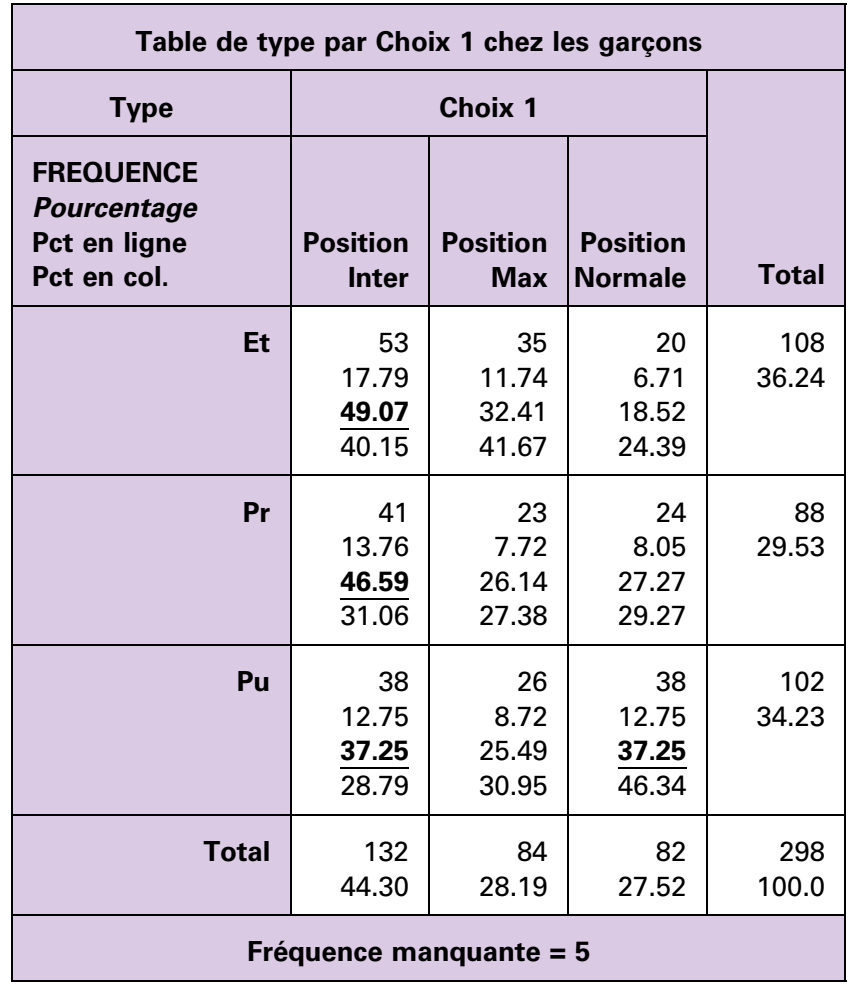

\section{Table VIII}

Preference in each jury for male mandibular position.

plains why juries chose a protruding profile. That is even more obvious in the results presented in sheet 9: neither practitioners nor students chose any hyperdivergent female profile.

On average, juries chose normal and intermediate profiles for boys and girls with normal lower facial height patients. As the initial mandibular position is preferred for short face patients, a short face tends to reduce the gap.

\section{3 - 2 - Judgement correlation statistical analysis}

Sex has no influence on the profile choice. Only the jury and facial type influence it. 


\begin{tabular}{|c|c|c|c|c|}
\hline \multicolumn{5}{|c|}{ Table de typologie par Choix 1} \\
\hline \multirow{2}{*}{\begin{tabular}{l}
\multicolumn{1}{c}{ Typologie } \\
FREQUENCE \\
Pourcentage \\
Pct en ligne \\
Pct en col.
\end{tabular}} & \multicolumn{3}{|c|}{ Choix 1} & \multirow[b]{2}{*}{ Total } \\
\hline & $\begin{array}{r}\text { Position } \\
\text { Inter }\end{array}$ & $\begin{array}{r}\text { Position } \\
\text { Max }\end{array}$ & $\begin{array}{c}\text { Position } \\
\text { Normale }\end{array}$ & \\
\hline Hyper & $\begin{array}{r}97 \\
16.22 \\
\mathbf{4 8 . 2 6} \\
38.65\end{array}$ & $\begin{array}{r}89 \\
14.88 \\
44.28 \\
54.60\end{array}$ & $\begin{array}{r}15 \\
2.51 \\
7.46 \\
8.15\end{array}$ & $\begin{array}{r}201 \\
33.61\end{array}$ \\
\hline Hypo & $\begin{array}{r}74 \\
12.37 \\
37.19 \\
29.48\end{array}$ & $\begin{array}{r}38 \\
6.35 \\
19.10 \\
23.31\end{array}$ & $\begin{array}{r}87 \\
14.55 \\
43.72 \\
47.28\end{array}$ & $\begin{array}{r}199 \\
33.28\end{array}$ \\
\hline Normo & $\begin{array}{r}80 \\
13.38 \\
\mathbf{4 0 . 4 0} \\
31.87\end{array}$ & $\begin{array}{r}36 \\
6.02 \\
18.18 \\
22.09\end{array}$ & $\begin{array}{r}82 \\
13.71 \\
\mathbf{4 1 . 4 1} \\
44.57\end{array}$ & $\begin{array}{r}198 \\
33.11\end{array}$ \\
\hline Total & $\begin{array}{r}251 \\
41.97\end{array}$ & $\begin{array}{r}163 \\
27.26\end{array}$ & $\begin{array}{r}184 \\
30.77\end{array}$ & $\begin{array}{r}598 \\
100.0\end{array}$ \\
\hline \multicolumn{5}{|c|}{ Fréquence manquante $=8$} \\
\hline
\end{tabular}

Table IX

Preferences in each jury according to facial typology.

Practitioners tend to choose a maximum or an intermediate profile compared to public preferences ( $p=0.0307$ for the maximum profile versus the normal profile, $p=0.059$ for the intermediate profile versus the normal profile). Students choice follows the same trend $(p=0.1046$ for the maximum profile versus the normal profile, $p=0.1055$ for the intermediate profile versus the normal profile).

Choice distribution regarding morphology is not the same for boys and for girls (significant interaction test $p<0.0001)$. This leads us to differentiate results in boys and in girls.

\begin{tabular}{|c|c|c|c|c|}
\hline \multicolumn{5}{|c|}{ Table de typologie par Choix 3} \\
\hline \multirow{2}{*}{$\begin{array}{l}\text { Typologie } \\
\text { FREQUENCE } \\
\text { Pourcentage } \\
\text { Pct en ligne } \\
\text { Pct en col. }\end{array}$} & \multicolumn{3}{|c|}{ Choix 3} & \multirow[b]{2}{*}{ Total } \\
\hline & $\begin{array}{r}\text { Position } \\
\text { Inter }\end{array}$ & $\begin{array}{r}\text { Position } \\
\text { Max }\end{array}$ & $\begin{array}{l}\text { Position } \\
\text { Normale }\end{array}$ & \\
\hline Hyper & $\begin{array}{r}12 \\
2.01 \\
5.97 \\
15.19\end{array}$ & $\begin{array}{r}31 \\
5.18 \\
15.42 \\
11.65\end{array}$ & $\begin{array}{r}158 \\
26.42 \\
78.61 \\
62.45\end{array}$ & $\begin{array}{r}201 \\
33.61\end{array}$ \\
\hline Нyро & $\begin{array}{r}26 \\
4.35 \\
13.07 \\
32.91\end{array}$ & $\begin{array}{r}126 \\
21.07 \\
63.32 \\
47.37\end{array}$ & $\begin{array}{r}47 \\
7.86 \\
23.62 \\
18.58\end{array}$ & $\begin{array}{r}199 \\
33.28\end{array}$ \\
\hline Normo & $\begin{array}{r}41 \\
6.86 \\
20.71 \\
51.90\end{array}$ & $\begin{array}{r}109 \\
18.23 \\
55.05 \\
40.98\end{array}$ & $\begin{array}{r}48 \\
8.03 \\
24.24 \\
18.97\end{array}$ & $\begin{array}{r}198 \\
33.11\end{array}$ \\
\hline Total & $\begin{array}{r}79 \\
13.21\end{array}$ & $\begin{array}{r}266 \\
44.48\end{array}$ & $\begin{array}{r}253 \\
42.31\end{array}$ & $\begin{array}{r}598 \\
100.0\end{array}$ \\
\hline & e & sante & & \\
\hline
\end{tabular}

Table IX bis

Distribution of choice 3 according to facial typology.

- In girls:

- Hyperdivergent and hypodivergent typologies preferentially lead the jury to choose a maximum or an intermediate profile in comparison with the normodivergent typology ( $p<0.0001$ in all cases).

\section{- In boys:}

- Hyperdivergent and hypodivergent typologies preferentially lead the jury to choose a maximum or an intermediate profile in comparison with the normodivergent typology ( $p<0.0001$ in both cases).

So, a boy with hyperdivergent typology has significantly more chances to 
have a maximum or an intermediate profile chosen compared to a boy with a normodivergent one.

- Hypodivergent typology preferentially leads to the choice of a normal profile in comparison to the normodivergent typology $(p<0.0001$ in all cases).

\section{4 - DISCUSSION}

\section{4 - 1 - Size and sample representativeness}

Figures were found out from a short sample of teenagers ( 3 girls and 3 boys). The bias comes from the subjective and the individual aspect of each face. A survey on a larger sample is the only way to reduce it.

We chose the patients regarding the characteristics written out in our "material et method".

\section{4 - 2 - Collection of data}

The constitution of our jury is balanced in terms of sex, age section, social membership (public, students, practitioners). Judgements are homogeneous and results of the different groups are well correlated. However, even though each type of jury is well represented, subtypes (orthodontists, dentists, students of different year courses) are not present enough.

\section{4 - 3 - Comparison with other studies}

In 2001, Massoni ${ }^{10}$ made a set of modifications of the naso-labial and chin areas from a profile taken in an advert from a woman's magazine (quite close to current aesthetic trends). His results on modification of the chin complete our work:

- forward and backward or up and down chin movements with a restricted length have no effect on the profile. Reducing the chin symphisis upward or backward only seems to soften the profile while increasing the chin symphisis hardens it.

- forward and down, and backward and up combined chin movements bring about a damaged profile, especially for a forward and up movement.

Werli $^{18}$ questioned fine arts students of Strasbourg in his study. They do not have the same preferences as the orthodontic norms.

- The favourite male profile is the most uptight whereas the favourite female one is convex.

- Profiles with a very backward chin are the least favourite.

- Nevertheless, the public favours a type of profile in which lips are more protrusive than in the orthodontics norms, as it is concluded by Czarnecki $^{4}$ and Hall ${ }^{7}$.

Other writers $9,12,13,15,17$ noticed (without any sexual or ethnic difference) a global preference for an uptight profile (orthognathia) in class I from orthodontics and the general public.

More recently, Miner, et al. ${ }^{11}$ have compared 24 children's own profile 
perceptions (before and after treatment) to the aesthetic preferences of their mothers and clinicians. Unlike clinicians, mothers and their children

\section{5 - CONCLUSION}

Every practitioner is an entity influenced by the education he received, his experience, his own sensitiveness. It is unthinkable that all could be systematised and lead to a unique and absolute taste. The main thing is that the practitioner takes his patients' desire into account while referring to aesthetic rules to direct his therapy.

Professional opinion compared to the one of the public, teaches us several things. Referring to the global results of our study, for both sexes and whatever the jury is, the favourite mandibular position is close to the normal (intermediate) or the maximum profile. The most retrusive profiles are the least appreciated. However, the sexual parameter is of influence: preferred a more protrusive subnasal profile compared to the initial one. But they tolerate less bringing forward the mandible.
- students and practitioners generally prefer more uptight female profiles.

- the public prefers more convex profiles. It does not generally appreciate too much protrusive chins, even in boys.

Moreover, the long lower facial height is felt as a harmful effect on a well balanced facial aesthetic. The vertical excess may be the most detrimental.

Unlike orthodontists, fine arts students do not consider that protruding the mandible improves the profile. In this type of evaluation, the guessing right is very subjective. As the systems of reference and fashion are in constant evolution, should orthodontists' evaluation change with time.

\section{REFERENCES}

1. Ben Amor A, Ben Amor F, Dhidah M. Approche morphologique de l'esthétique faciale: une etude tunisienne. Orthod. Fr 2003;74:467-472.

2. Beugre JB, Beugre-Kouassi AMI, Sonan NK, N'Dindin-Guinan B, Fareou P, Faure J, Djaha K. Céphalométrie comparative et appréciation esthétique faciale en Afrique Noire Subsaharienne. Biom Hum et Anthropol 2005;23:63-72.

3. Coleman GG, Lindauer ST, Tüfekci E, Shroff B, Best Al. Influence of chin prominence on esthetic lip profile preferences. Am J Orthod Dentofacial Orthop 2007;132:36-42.

4. Czarnecki ST, Nanda RS, Currier GF. Perceptions of a balanced facial profile. Am J Orthod Dentofacial Orthop 1993 Aug;69(3):231-8.

5. De Coster T. Étude comparative des critères d'évaluation céphalométrique du profil cutané. Orthod Fr 1991;62:559-72.

6. Faure J, Bolender Y. L'appréciation esthétique sociale : revue de littérature. Rev Orthop Dento Faciale 2004;38:61-92.

7. Hall D, Taylor RW, Jacobson A, Sadowsky PL, Bartolucci A. The perception of optimal profile in African Americans versus white Americans as assessed by orthodontists and the lay public. Am J Orthod Dentofacial Orthop 2000;118:514-25. 
8. Hier LA, Evans CA, Begole EA, Giddon DB. Comparison of preferences in lip position using computer animated imaging. Angle Orthod 1999 Jun;69(3):231-8.

9. Kerr WJ, Renard HR. Normes orthodontiques et canons artistiques: étude comparative. Rev Orthop Dento Faciale 1992;26:61-9.

10. Massoni M, Favot P. Traitement informatique et évaluation du profil en ODF. Revue d'Odontostomatologie 2001;t.30,4:193-200.

11. Miner RM, Anderson NK, Evans CA, Giddon DB. The perception of children's computer-imaged facial profiles by patients, mothers and clinicians. Angle Orthod 2007 Nov;77(6):1034-9.

12. Orsini G, Huang GJ, Kiyak HA, Ramsay DS, Bollen AM, Anderson NK, Giddon DB. Methods to evaluate profile preferences for the anteroposterior position of the mandible. Am J Orthod Dentofacial Orthop 2006;130:283-91.

13. Phillips C, Griffin T, Bennett E. Perception of facial attractiveness by patients, peers and professionals. Int J Adult Orthod. Orthognath Surg 1995;10(2):127-35.

14. Rhodes G, Yoshikawa S, Clark A, Lee K, Mckay R, Akamatsu S. Attractiveness of facial averageness and symmetry in non-western cultures, in search of biologically based standard of beauty. Perception 2001;30(5):611-62.

15. Soh J, Chew MT, Wong HB. A comparative assessment of the perception of Chinese facial profile esthetics. Am J Orthod Dentofacial Orthop 2005;127:692-699.

16. Spyropoulos MN, Halazonetis DJ. Significance of the soft tissue profile on facial esthetics. Am J Orthod Dentofacial Orthop 2001;119:464-71.

17. Viana G, Park YS, Anderson NK, Evans CA, Giddon DB. Profile preferences of Korean American orthodontic patients and orthodontists. World J Orthod 2006 fall;7(3):286-92.

18. Werli T, Mathis R, Hedelin G, Rothea-Gouillard C. Evaluation du profil cutane par les etudiants en arts plastiques. Rev Orthop Dento Faciale 2003;37:145-156. 